Creative Commons User License: CC BY-NC-ND

Abstracted by: EBSCOhost, Electronic Journals Service (EJS), Google Scholar, Journal Seek, Scientific Commons,

Food and Agricultural Organization (FAO), CABI and Scopus

http://eoi.citefactor.org/10.11226/v26i1
Journal of Agricultural Extension

Vol. 26 (1) January, 2022

ISSN(e): 24086851; ISSN(Print); $1119944 \mathrm{X}$

http://journal.aesonnigeria.org

http://www.ajol.info/index.php/jae

Email: editorinchief@aesonnigeria.org

\title{
Cocoa-Farmers' Preferred Training Schedule on Good Agricultural Practices in Ondo State, Nigeria
}

https://dx.doi.org/10.4314/jae.v26i1.8

\author{
Akinmolafe, Abiodun Oladele \\ Department of Agricultural Extension and Communication Technology, Federal University of \\ Technology, Akure, Nigeria \\ akinmolafeabiodun33@gmail.com +2347033221182 \\ Ajayi, Adedayo Olufemi \\ Department of Agricultural Extension and Rural Development, Obafemi Awolowo University, \\ lle-Ife, Nigeria \\ dayoajayi@oauife.edu.ng +2348034092337
}

\begin{abstract}
The study examined cocoa farmers' preferred training schedule on good agricultural practices (GAP) in Ondo State, Nigeria. A total of 294 cocoa farmers were sampled through a multi-stage sampling procedure. Data were collected on respondents' personal and socio-economic characteristics, perceived knowledge level in selected cocoa production management practices, method of training, form of training, venue of training, time of the year (month) for training and medium of expression. Data were analyzed using mean, standard deviation and percentage. The study revealed that cocoa farmers can read and write Yoruba language (86.1\%), the majority (75.6\%) had between $6-17$ years of formal education, and $60.9 \%$ were participating in religious organization. Cocoa farmers preferred practical demonstration method of training (85.4\%) and training in groups (96.6\%). They also preferred training at farm site (83.0\%) as well as using the local dialect (60.9\%) as medium of communication. Any training for cocoa farmers should be designed using practical demonstration and small plot adaptive technique.
\end{abstract}

Keywords: Cocoa farmers, training schedule, good agricultural practices

\section{Introduction}

Cocoa is an important generator of income for most rural farmers in Nigeria especially in the South West and serves as a backbone for their livelihood (Akinnagbe, Adeniran and Adeniran 2018). The quality and quantity of cocoa beans reduced drastically thus made Nigeria to fell in rank to $5^{\text {th }}$ position in the world.

The reduction in quality and quantity of cocoa beans is due to a lot of natural and human factors. The management practices employed by cocoa farmers such as land 
Creative Commons User License: CC BY-NC-ND

Abstracted by: EBSCOhost, Electronic Journals Service (EJS),

Google Scholar, Journal Seek, Scientific Commons,

Food and Agricultural Organization (FAO), CABI and Scopus

http://eoi.citefactor.org/10.11226/v26i1
Journal of Agricultural Extension

Vol. 26 (1) January, 2022

ISSN(e): 24086851; ISSN(Print); $1119944 \mathrm{X}$

http://journal.aesonnigeria.org

http://www.ajol.info/index.php/jae

Email: editorinchief@aesonnigeria.org

selection, planting materials, shading, pruning, mulching, weeding, fertilizer application, harvesting, fermentation, drying to packaging among others are the factors which had much to do with the production of this crop. Coupled with these practices, the Future Agriculture Consortium (2019), submitted that most of the cocoa trees in Nigeria are old with diminishing production trend. These old trees coupled with their susceptibility to pest attack and poor management practices are responsible for the decline in the quality and quantity of cocoa production in the country. This however, calls for rehabilitation of the old cocoa trees and deployment of good practices in cocoa production management which cocoa farmers cannot embark upon without training from the experts.

The Food and Agricultural Organization (FAO) came up with a management practice called good agricultural practices (GAP). Stakeholders in crop productions are expected to adopt these practices to boost crop productions in their respective countries. FAO (2016), defines the good agricultural practices (GAP) as a collection of principles for on-farm production and postproduction processes, resulting in safe and healthy food and non-food agricultural products, while taking into account economic, social and environmental sustainability. FAO definition of GAP emphasized that there are steps to systematically follow in all on-farm and postproduction processes which will bring about sustainability in all facets of farming activities.

To ensure that cocoa farmers have the required skills in the stated management practices there is need to train them to become more skilful when carrying out these practices on the field. Training is a set of pre-organized set of activities that helps in the shaping of skills, attitudes and knowledge of employees in order to contribute positively to the productivity of the organization. Every training process involves educational methods which can guarantee an effective learning. Related to learning in agricultural extension is training which is acquisition of knowledge, skill and attitude. Which must follow a systematic and well organized process(es).

Nwaobiala C. U., Ndukwe I. and Ekumankama O. (2016), defined training as acquiring information and development abilities or attitudes, which result to greater competence in the performance of a worker. In training design, there are four main areas that need to be taken into consideration. These include, what learning outcomes will meet the needs of the learners, what aspects should be included in the creation of the training plan, what resources are available, as it is vital to take into account the resources, especially the finances and what are some potential challenges to this training program. In the design of the training programmme, there are some challenges that take place and it is vital to put into practice the measures to make provision of solutions to these challenges. 
Creative Commons User License: CC BY-NC-ND

Abstracted by: EBSCOhost, Electronic Journals Service (EJS), Google Scholar, Journal Seek, Scientific Commons,

Food and Agricultural Organization (FAO), CABI and Scopus

http://eoi.citefactor.org/10.11226/v26i1
Journal of Agricultural Extension

Vol. 26 (1) January, 2022

ISSN(e): 24086851; ISSN(Print); $1119944 X$

http://journal.aesonnigeria.org

http://www.ajol.info/index.php/jae

Email: editorinchief@aesonnigeria.org

The study:

i. determined farmers' knowledge level in good agricultural practices in cocoa production;

ii. ascertained cocoa farmers preferred training schedule on GAP.

\section{Methodology}

The study was carried out in Ondo state Nigeria. It lies between latitude $5^{0} 45^{1}$ and $8^{0}$ $15^{1}$ North and longitude $4^{0} 45^{1}$ and $6^{0}$ East,. It has a population of $3,460,877$ (National Population Census 2006). The state is made up of four agricultural development zones (ODSADEP). They are; Ikare, Okitipupa, Ondo, and Owo zones.

The study population comprised men, women and youths that are involved in cocoa farming. Multistage sampling procedure was adopted for the study. At the first stage fourteen cocoa producing local government areas (LGAs) in the state were purposively selected. At the second stage, $50 \%$ of the 14 cocoa producing LGAs were randomly selected using proportionate sampling technique to give approximately three LGAs from Ondo zone, two LGAs from Owo zone, two LGAs from Okitipupa zone and one LGA from Akoko zone to give a total of eight LGAs. At the third stage, three village communities that mainly produce cocoa were purposively selected from each of the selected LGAs to give a total of twenty four village communities. At the fourth stage, cocoa farmers' households were randomly sampled where at least twelve cocoa farmers were selected from each sampled village communities to give a total sample of 294 respondents. Pre-tested interview schedule on a range of variables including data on farmers' personal and social economic characteristics, knowledge level in cocoa production and preferred training schedule. The personal and socioeconomic characteristics selected were sex, marital status and education level). Focus group discussion was used to report qualitative data.

Table 1: Sample selection

\begin{tabular}{ccccc} 
Zone & $\begin{array}{c}\text { Cocoa } \\
\text { producing } \\
\text { (LGAs) }\end{array}$ & $\begin{array}{c}\mathbf{5 0 \%} \text { of } \\
\text { LGAs }\end{array}$ & $\begin{array}{c}\text { Selected village } \\
\text { communities }\end{array}$ & $\begin{array}{c}\text { Cocoa farmers } \\
\text { household }\end{array}$ \\
\hline Akoko & 2 & 1 & 3 & 36 \\
Okitipupa & 3 & 2 & 6 & 72 \\
Ondo & 5 & 3 & 9 & 114 \\
Owo & 4 & 2 & 6 & 72 \\
Total & $\mathbf{1 4}$ & $\mathbf{8}$ & $\mathbf{2 4}$ & $\mathbf{2 9 4}$ \\
\hline
\end{tabular}


Creative Commons User License: CC BY-NC-ND

Abstracted by: EBSCOhost, Electronic Journals Service (EJS), Google Scholar, Journal Seek, Scientific Commons,

Food and Agricultural Organization (FAO), CABI and Scopus

http://eoi.citefactor.org/10.11226/v26i1
Journal of Agricultural Extension

Vol. 26 (1) January, 2022

ISSN(e): 24086851; ISSN(Print); $1119944 X$

http://journal.aesonnigeria.org

http://www.ajol.info/index.php/jae

Email: editorinchief@aesonnigeria.org

\section{Results and Discussions}

\section{Personal characteristic}

Table 2 shows that the farmers can read and write Yoruba language (86.1\%) Pidgin English (15\%), the English language (37.1\%), other languages (Hausa and Ibo) languages $(2.4 \%)$. This shows that farmers would be able to write down important information during training programme which they can assess later when the need arises.

On years of formal education, the majority (75.6\%) had between $6-17$ years, 18 years and above (3.1\%) and less than 6 years (21.4\%). The mean year of formal education among cocoa farmers was $8.3 \pm 4.6$. This implies that farmers can actually respond to training since educated people tend to adopt technological innovation more readily than their uneducated counterparts.

Table 2 indicates that $60.9 \%$ of the respondents were participating in religious organization, social club (49.3\%), cooperative society (33.7\%), community development association (25.5\%) and indigenous union (21.4\%). This supported the findings of Akinnagbe et al., (2018), that 58.1 percent of cocoa farmers belong to one organization or the other. These organizations can be effective as platforms for disseminating information related to training.

\section{Table 2: Personal characteristic}

\begin{tabular}{lccc}
\hline Variable & Percentage & Mean & SD \\
\hline Years of formal education & & & \\
$\leq 6$ & 21.4 & 8.3 & 4.6 \\
$6-11$ & 46.3 & & \\
$12-17$ & & 29.2 & \\
$18+$ & & & \\
Literacy & 86.1 & & \\
Yoruba (read \& write) & 15.0 & & \\
Pidgin (read \& write) & 37.1 & & \\
English (read \& write) & 2.4 & & \\
Others (read \& write) & & & \\
Organizational participation & 60.9 & & \\
Religious group & & 49.3 & \\
Social club & & 33.7 & \\
Cooperative society & 25.5 & \\
Community Dev. Assoc. & & 21.4 \\
Indigenous Union & 2.4 & & \\
Others & &
\end{tabular}


Creative Commons User License: CC BY-NC-ND

Abstracted by: EBSCOhost, Electronic Journals Service (EJS),

Google Scholar, Journal Seek, Scientific Commons,

Food and Agricultural Organization (FAO), CABI and Scopus

http://eoi.citefactor.org/10.11226/v26i1
Journal of Agricultural Extension

Vol. 26 (1) January, 2022

ISSN(e): 24086851; ISSN(Print); $1119944 \mathrm{X}$

http://journal.aesonnigeria.org

http://www.ajol.info/index.php/jae

Email: editorinchief@aesonnigeria.org

\section{Perceived Knowledge Level in selected Cocoa Production Management Practices}

Table 3 reveals that cocoa farmers had high knowledge in choice of planting materials $(\bar{x}=3.63)$, nursery maintenance $(\bar{x}=3.47)$, land selection $(\bar{x}=3.42)$, field cultivation techniques $(\bar{x}=3.31)$, maintenance of organic matter $(\bar{x}=3.24)$ and low knowledge in efficient use of farm resources ( $\bar{x}=3.23)$, Agro-forestry management $(\bar{x}=2.85)$. The grand mean was 3.24. These findings revealed that cocoa farmers had high knowledge in plantation establishment. This is an indication that farmers in the study area have been establishing cocoa plantation knowledgably. This corroborated the findings of Omoare, Oyediran and Fakoya (2016) that cocoa farmers practice cocoa plantation establishment in appropriate manners. However, the low knowledge recorded in efficient use of farm resources and agro-forestry management indicated that these practices were aliens to the cultural practices known by cocoa farmers. Thus, experts or professionals in these areas may be involved in training them for more knowledge.

Cocoa farmers had high knowledge in appropriate weed control $(\bar{x}=3.73)$ timely pruning $(\bar{x}=3.69)$, adequate use of organic/inorganic fertilizer $(\bar{x}=3.42)$, fertilizer application $(\bar{x}=3.40)$, optimum use of farm labours $(\bar{x}=3.38)$ but low knowledge in the following: efficient irrigation facilities $(\bar{x}=2.61)$ and farm sanitation $(\bar{x}=3.32)$. The grand mean for the practices in this section was 3.36. These findings revealed that cocoa famers had high knowledge in routine management practices. This is an indication that cocoa farmers had expertise in routine practices that were commonly practiced among them. This is in consonance with the findings of Omoare et.al. (2016) that these practices were regular activities carried out by cocoa farmers. However, farm sanitation and efficient irrigation practices where they had low knowledge indicates that these practices were not regularly practice, therefore they may require support to become expert in them.

The study reveals that on climate change adaptation techniques cocoa farmers had high knowledge in the following, fire tracing $(\bar{x}=3.81)$ and mulching $(\bar{x}=3.62)$, however, farmers had low knowledge in soil management $(\bar{x}=2.88)$ and shade management $(\bar{x}=2.73)$. These findings revealed that cocoa famers had high knowledge in some climate change adaptation techniques, they were; fire tracing and mulching but low knowledge in soil management and shade management. This implies that cocoa farmers' knowledge on climate change should be increased through more sensitization or training in the area of low knowledge. 
Creative Commons User License: CC BY-NC-ND

Abstracted by: EBSCOhost, Electronic Journals Service (EJS), Google Scholar, Journal Seek, Scientific Commons,

Food and Agricultural Organization (FAO), CABI and Scopus

http://eoi.citefactor.org/10.11226/v26i1
Journal of Agricultural Extension

Vol. 26 (1) January, 2022

ISSN(e): 24086851; ISSN(Print); 1119944X

http://journal.aesonnigeria.org

http://www.ajol.info/index.php/jae

Email: editorinchief@aesonnigeria.org

Table 3: Cocoa farmers level of knowledge of cocoa production techniques

Knowledge Mean SD

Plantation establishment

Choice of planting materials

$3.63 \quad 1.01$

Nursery maintenance

3.47

1.11

Land selection

3.42

0.95

Field cultivation techniques

3.31

1.17

Maintenance of organic matter

3.24

1.24

Efficient use of farm resources

$3.23 \quad 1.30$

Land tillage system

$3.22 \quad 1.28$

Field layout

$3.02 \quad 1.26$

Good habitat selection

3.00

1.24

Agro forestry management

$2.85 \quad 1.29$

Grand mean

3.24

Routine management practices

Appropriate weed control

3.73

.907

Timely pruning

3.69

.960

Adequate use of organic/inorganic fertilizer

3.42

1.11

Fertilizer application in cocoa production

3.40

1.10

Optimum use of farm labour

3.38

1.09

Farm sanitation

3.32

1.21

Efficient irrigation facilities

Grand mean

2.61

1.34

Climate change adaptation technique

Fire Tracing

3.36

Mulching

3.81

.928

Soil management in cocoa production

3.62

.978

Shade management

2.88

1.29

Grand mean

1.35

2.73

\section{Method of training}

Table 5 indicates that the majority (85.4\%) of the respondents preferred practical demonstration method and small plot adaptive technique $(52.4 \%)$ to lecture and discussion method (16.7\%), audio visual (cinemas and films) $(7.5 \%)$, radio $(7.1 \%)$ and printed materials (5.8\%). This shows that adult learners learn more from practical demonstration than any other methods of training. Therefore, any workshop that will be organized should be designed using practical demonstration method and small plot 
Creative Commons User License: CC BY-NC-ND

Abstracted by: EBSCOhost, Electronic Journals Service (EJS), Google Scholar, Journal Seek, Scientific Commons,

Food and Agricultural Organization (FAO), CABI and Scopus

http://eoi.citefactor.org/10.11226/v26i1
Journal of Agricultural Extension

Vol. 26 (1) January, 2022

ISSN(e): 24086851; ISSN(Print); 1119944X

http://journal.aesonnigeria.org

http://www.ajol.info/index.php/jae

Email: editorinchief@aesonnigeria.org

adaptive technique as training method. This is an indication that cocoa farmers will be more relaxed when training is practical which will enable them to follow any training step by step. Once the farmers are trained using a practical method, transferring of acquired knowledge will be easier, thus enable them improved their production through good agricultural practices.

\section{Form of training}

Results in Table 5 indicate that the majority the (96.6\%) preferred training in group with other farmers, alone (one-to-one with the trainer) (9.5\%) and cooperative meeting (7.5\%). This shows that learning in group by adult learners assist them to learn better and faster than learning alone in isolation. This supports the position of Feed the Future (2019), In delivering the training, the facilitators adopted practical training methods like team work exercises, case studies, fish bowl, brainstorming, and facilitated discussions. This was to ensure irrespective of literacy levels, the participants were able to engage and learn effectively. So, after the training, participants can share ideas and opinions with each other, thus bring about quick assimilation and healthy competition among cocoa farmers.

\section{Venue for training}

The Table shows that many (83.0\%) preferred trainings at the farm, home (13.3\%), village centre $(23.5 \%)$, local government headquarter $(1.0 \%)$, urban centre $(1.4 \%)$ and state capital $(2.4 \%)$. That cocoa farmers preferred training at the farm means that they will be more relaxed in their farm than any other venue. This supported the recommendation of FAO (2016), that workshops should be held at or near farms where demonstrations sites are located. This will prevent spending money on transport fare to venues outside their immediate community.

\section{Time of the year (month) for training}

The Table also reveals cocoa farmers' preference on time of the year for training as follows: between the months of January/February (65.3\%), November/December (16.0\%) and March - October (10.0\%). This corroborates the report from focus group discussion conducted in Irele Local Government where farmers said that,

"There are less job to attend to in our farms either for food crops or cash crops in the months of January and February."

Therefore, this was evidence that farmers will readily attend a training programme in the stated months than any other months because January and February are months classified by farmers as free months, when there will be less work in their farms. The time of the year for training must be in consonance with the free period of the farmers, 
Creative Commons User License: CC BY-NC-ND

Abstracted by: EBSCOhost, Electronic Journals Service (EJS),

Google Scholar, Journal Seek, Scientific Commons,

Food and Agricultural Organization (FAO), CABI and Scopus

http://eoi.citefactor.org/10.11226/v26i1
Journal of Agricultural Extension

Vol. 26 (1) January, 2022

ISSN(e): 24086851; ISSN(Print); 1119944X

http://journal.aesonnigeria.org

http://www.ajol.info/index.php/jae

Email: editorinchief@aesonnigeria.org

because farmers will easily prioritize farming work over any training if there is clash of time.

\section{Day of the Week}

The Table indicates farmers' preference on day of the week that training should be scheduled as follows: Saturday (49.0\%), Monday (25.5\%), Tuesday (12.6\%), Wednesday $(7.8 \%)$, Friday $(5.4 \%)$, Sunday $(5.4 \%)$ and Thursday $(3.4 \%)$. The result revealed that farmers preferred Saturday to any other days. This was an indication that cocoa farmers have to relax from all works during the weekend, so training at the weekend would be preferable. This study revealed that farmers participated in one organization or the other, so their preference of particular day of the week over others for training must have been a resolve that they are free from all activities, farming and organizational.

\section{Time of the day}

The result in the Table indicates the preference of cocoa farmers on time of the day training should be scheduled; evening (63.9\%), morning (34.0\%) and afternoon $(3.1 \%)$. These findings revealed that cocoa farmers preferred training to come up in the evening. The implication of this is that for training programmes on GAP to be successful, farmers' specified time of the day should be considered. This supported the findings of FAO (2016) that workshops and field days show higher attendance outside of the dry season and in the late morning or evening. This implies that scheduling of training programme on GAP for cocoa farmers in the evening is a welcome idea. However, the exact time in evening should be strictly adhere to because nightfall can disrupt any programme if time is not well managed.

\section{Duration of the training}

The result in Table indicates that farmers will appreciate $1-2$ days training programme $(68.7 \%)$ seven days $(24.5 \%)$ four weeks $(6.1 \%)$. These findings revealed that cocoa farmers preferred $1-2$ days training programme to other durations. The implication of this is that farmers want compressed training package. Although this compressed training programme may not address all their training needs, because the practical aspect of the training must be detailed and may not be fully disseminated within one to two days.

\section{Medium of expression}

The result in the Table reveals that farmers preferred local dialect of their respective communities to any other language. This however, reflected in the respondents preferred language of expression with $60.9 \%$ chose local dialect while $47.6 \%$ opted for English/Local Dialect and only 4.1\% preferred English/Pidgin English. This result 
Creative Commons User License: CC BY-NC-ND

Abstracted by: EBSCOhost, Electronic Journals Service (EJS),

Google Scholar, Journal Seek, Scientific Commons,

Food and Agricultural Organization (FAO), CABI and Scopus

http://eoi.citefactor.org/10.11226/v26i1
Journal of Agricultural Extension

Vol. 26 (1) January, 2022

ISSN(e): 24086851; ISSN(Print); 1119944X

http://journal.aesonnigeria.org

http://www.ajol.info/index.php/jae

Email: editorinchief@aesonnigeria.org

suggests that for effective communication of information on GAP local dialect of the farmers should be considered to be more appropriate. Learning to speak the farmer's own language is a goal most extensionists work towards in some way or another. Learning to use a language in a culturally appropriate way may in many respects be a more useful objective (Humanity Development Library 2.0).

Table 5: Preferred training schedule of respondents

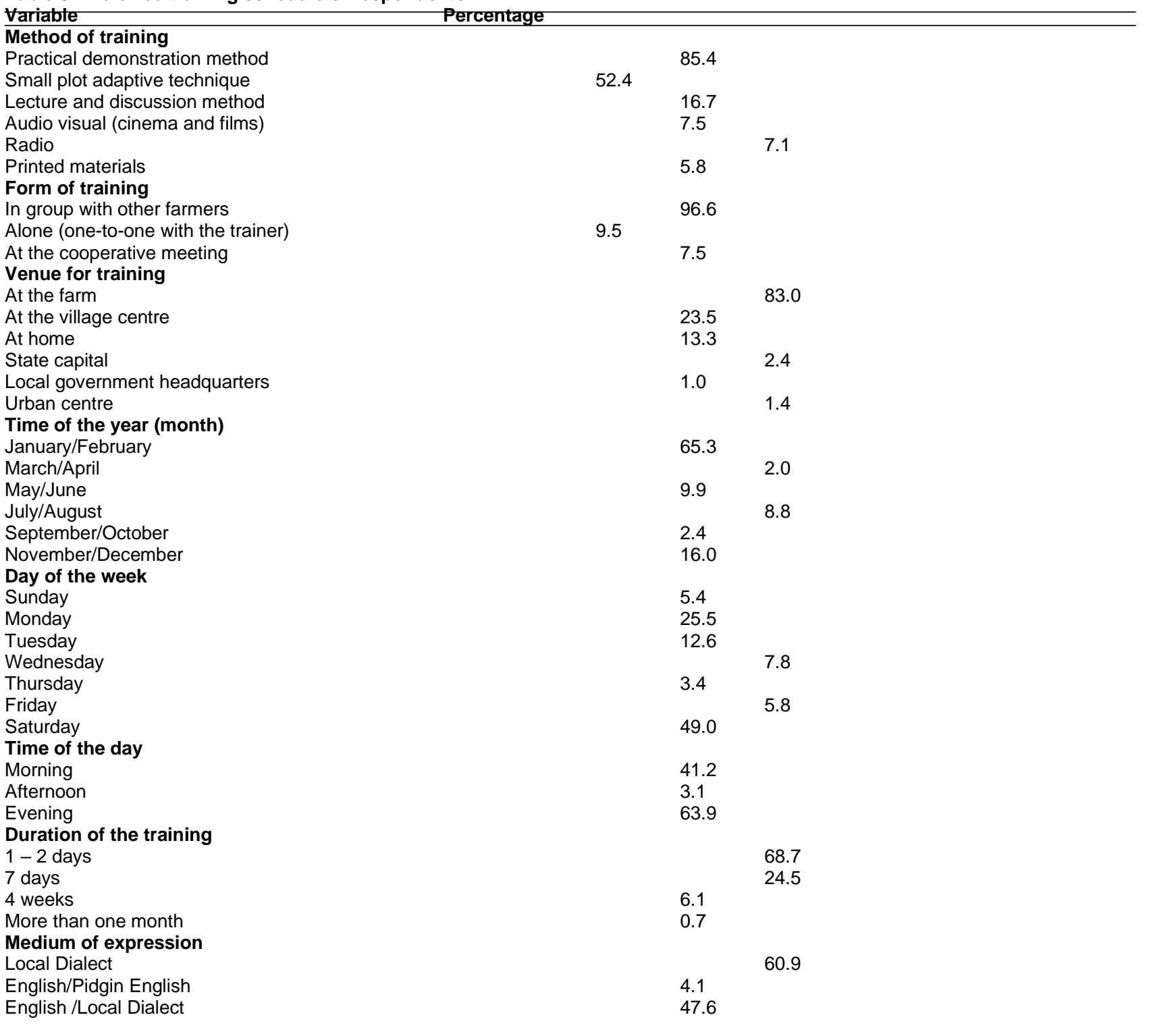


Creative Commons User License: CC BY-NC-ND

Abstracted by: EBSCOhost, Electronic Journals Service (EJS), Google Scholar, Journal Seek, Scientific Commons, Food and Agricultural Organization (FAO), CABI and Scopus

http://eoi.citefactor.org/10.11226/v26i1
Journal of Agricultural Extension

Vol. 26 (1) January, 2022

ISSN(e): 24086851; ISSN(Print); 1119944X

http://journal.aesonnigeria.org

http://www.ajol.info/index.php/jae

Email: editorinchief@aesonnigeria.org

\section{Conclusion and Recommendations}

Practical demonstration and small plot adaptive technique were mostly chosen as medium of training by the cocoa farmers. They preferred that training come up in their farms and in group with others. Efforts should be made to reach farmers through their affiliated organizations since most of the cocoa farmers belong to one or more organization and it is presumed that dissemination of information spread rapidly among these affiliated organizations. The preference of cocoa farmers for training schedule and implementation should be considered since cocoa farmers are adults that are self-directed in learning. Government, non-governmental organizations, International bodies and other agricultural stakeholders should ensure that trainings are organized for farmers to increase their knowledge in cocoa production managements practices with low knowledge.

\section{References}

Abidogun, O. G., Olajide, B. R., Amujoyegbe, B. J., B amire, A. S., Kehinde, A. D. and Gaya, I. (2019) Gender involvement in cocoa farming activities in South West Nigeria. Ife Journal of Agriculture, 31(1), 53 - 62.

Akinnagbe, O. M., Adeniran, T. P. and Adeniran, A. A. (2018) Intra-Household Roles in Cocoa Production in Ondo State, Nigeria. Journal of Agricultural Extension 22(3), 77 86.

Feed the future: Nigeria Agricultural policy (2019) Group Dynamics Training for Farmer Groups in Niger State. An article posted on 17th October, 2019.

Food and Agriculture Organization of the United Nations (FAO) 2016. A scheme and Training Manual on Good Agricultural Practices (GAP) for Fruits and Vegetables. The scheme

- $\quad$ standard and implementation infrastructure. Vol. 1 access fao.org/3/i6677e/i6677e.pdf on 25th June, 2021.

Food and Agriculture Organization of the United Nations (FAO) 2016. Conducting Farm Based Trainings on how to enhance On-Farm Ecosystem Services Inspiring the Far Community to Adopt New Practices. Biodiversity and Ecosystem Services in Agricultural Production System access on www.fao.org/publications.

Future Agricultures Consortium (2019) The Future of Cocoa Production in Nigeria: An Account of Adegeye's Extensive Research Experiences. Access on futureagricultures.org/blog on 17th June, 2021. 
Creative Commons User License: CC BY-NC-ND

Abstracted by: EBSCOhost, Electronic Journals Service (EJS),

Google Scholar, Journal Seek, Scientific Commons,

Food and Agricultural Organization (FAO), CABI and Scopus

http://eoi.citefactor.org/10.11226/v26i1
Journal of Agricultural Extension

Vol. 26 (1) January, 2022

ISSN(e): 24086851; ISSN(Print); 1119944X

http://journal.aesonnigeria.org

http://www.ajol.info/index.php/jae

Email: editorinchief@aesonnigeria.org

Humanity Development Library 2. 0: for sustainable development and basic human needs. A training manual accessed on nzdl.org/cgi-bin/library on 17th November, 2021

National Population Census, 2006. http://www.nigeriavillagesquare.com/articles/nvs/npcreleases-2006-population-figures-14 html (accessed on 02/07/2021).

Nwaobiala C. U., Ndukwe I. and Ekumankama O. (2016) Assessment of training needs of cocoa farmers in Bende Local Government Area of Abia State, South East Nigeria, Scientific Papers Series Management, Economic Engineering in Agriculture and Rural Development 16 (4) ISSN 2284-7995, E-ISSN 22853952.

Olasupo, F. O. and Aikpokpodion, P. O. (2019) Cacao genetic resources conservation and utilization for sustainable production in Nigeria (Online Firs), Intechopen DOI:10.5772/intechopen. 82703.

Omoare, A. M., Oyediran W. O. and Fakoya E. O. (2016) Comparative assessment of cocoa farmer' knowledge and attitude to trainings on good cultural management practices

Extension and Rural Development Studies 3(3); 36-51.

(CMP) in Ogun and Ondo States, Nigeria, International Journal of Agricultural

Uwagboe, E. O., Famuyiwa, B. S. and Agbebaku, E. E. O. (2016) Cocoa farmers attitude towards utilisation of integrated pest management in Edo and Ogun States of Nigeria. Journal of Agricultural Extension 20 (2); 67 -79. 